\title{
Implication Principles Of Carousel Brainstorming Strategy As An Effeciency Motivation For Improving Reading Comprehensionin Pandemic Era
}

\author{
Syamsul Rizal ${ }^{1}$, Ferri Susanto $^{2}$ \\ ${ }^{1,2}$ English Department of Institut Agama Islam Negeri Bengkulu,Indonesia \\ Corresponding Author \\ *Email : ferialfa02@gmail.com
}

\begin{abstract}
.
This research was Constitutional law program students IAIN of Bengkulu that they haveless motivated and learning reading comprehension is bored, only 120 minutes in a week to study English at Faculty. The purpose of this research explain whether using Carousel Brainstorming Strategy can improve students' Reading comprehension IAIN Bengkulu especiallyConstitutional law program students IAIN of Bengkuluin Academic year 2019/2020. Therefore, this research by Descriptive Qualitative and quantitative dataThe subjects instruments of this research were 30 students, consisted of females 23 and 7 males. The instruments of this research were reading tests, students observation checklists andlecturer observation checklist and fiels notes, and interview. The result of students mean score in Pre-assessment and every meeting, there are improvement in pre-assessment $(50,1)$, The first meeting $(62,43)$, and The second meeting (75,33). This research shows that using Carousel Brainstorming Strategy has successfully improved the students reading comprehension, the improvement was influenced by the used of interesting material chosen and lecturer's participation toward the students.
\end{abstract}

Keywords: Carousel Brainstorming Strategy.

\section{INTRODUCTION}

Statements from Government in order to society could do for independent isolation by not leaving the house, except in urgent conditions, in order to break the chain of the spread of the COVID-19 corona, the public formed a different routine with limited space and minimal mobility. These situations also effected for learning process especially for reading habbit for public. Learning strategy and motivation are fundamental component how to change the habbitual action in learning. The public is also worried about facing uncertainty about how long this condition will end. "As if society is in a state of 'war' against the enemy of the 'virus' which is uncertain. How to develope manythings about constructive and inovative thinking and they must be suppoted by the high motivation in order to public still consitent for lerning process especially creating the new habbit for reading in the pandemic era by develope brainstorming strategy by Carousel. It is hoped that can be solution for reading process especially for students.Abualzain ,O, I. (2017) stated that the history of reading goes back to the invention of writing. Reading is of great significance human life, therefore, it is the main factor in the acquisition of expertise and knowledge.

Lethargy and low motivation of students to manage knowledge also have an effect on the current pandemic conditions, a global pandemic can have a considerable influence on the development of science, especially in the learning process, for that all learning activities must have the best solution to help students and the public to cope. the learning crisis that is taking place during this pandemic. Learning strategies are principles that can solve this problem. Crousel Brainstorming is one strategy that is considered capable of overcoming the low interest of students in learning, especially in reading. Brainstorming is a form of discussion in order to gather ideas, opinions, information, knowledge, experiences, from all participants. In contrast to discussions, where someone's ideas can be responded to (supported, complemented, reduced, or not agreed upon) by other participants, the use of the brainstorming method for other people's opinions is not to be responded. Realizing of the importance of the reading comprehension, the writer introduces of a strategy to get a student successful in reading namely Carousel Brainstorm Strategy. Jones said that this strategy gives contribution for the student in processing information, communicating, developing thinking review of material and checking prior knowledge. Rubel, Mcknigth (2013), carousel brainstorming provides an opportunity to generate lots of ideas in response to different prompts as well as to the thingking of the other group. Point out that carousel brainstorming allow a lecturer to have students pull out and thingking about what they know about subtopic whitin a large topic in reading. ${ }^{1}$ She adds that this strategy is also activating background knowledge and to check understanding after studying a general topic. McKnight says carousel brainstorming is a graphic organizer that can be used for brainstorming a topic to improve reading skill. 
According these phenomena, it is clear enough that reading comprehension of IAIN Bengkulu especially for Syariah Faculty still have some problems. So the writer tries to apply one of strategies that increase students reading comprehension Carousel Brainstorming Strategy. This strategy can be viewed as a suitable strategy used in the teaching reading in pandemic era, Corousel Brainstorming strategy is appoprite it for teaching reading comprehension.It requires students to accsess background knowledge or review what they have learned by thingking about subtopic within a boarder topic.This strategy also increase students' reading skill.Carousel Brainstorming strategy can also be used in teaching reading In this strategy students are talking or having discussion about what they are reading, and consequently developing their comprehension of infomattional. This is an awesome way get students interested in content, focused on what they are reading and focused them monitor their comprehension .The aim of a Carousel Brainstorming program is to help students to enjoy reading.Based on the description and phenomena above, the writer is interested in to carry out a research entitled"IMPLICATION PRINCIPLES OF CAROUSEL BRAINSTORMING STRATEGY AS AN EFFECIENCY MOTIVATION FOR IMPROVING READING COMPREHENSION IN PANDEMIC ERA"

\section{METHODS}

This research used descriptive qualitative method because it describes the recent phenomena of hesitation disfluencies in English Reading by Constitutional law program students IAIN of Bengkulu Qualitative research is the research that focuses on specific situation or people, and it emphasize on words rather than number and this research got sentence data such as oral and written from people or subject.Qualitative research is based on a different Philosophical approach, which sees the individual and his or her world as so interconnected that essentially the one has no existence without the other.Cresswell (1994: 147) Qualitative research is an interpretative research. Setting and subject of this research was conducted atSyariah Faculty especially Constitutional law program of IAIN Bengkulu. This subject of the researchwas the students of Constitutional law program 3 classes. The number of the students in family law classesare 30. The research choose these classes because they have problems of reading comprehension in narrative text. Morever,the main score of the students reading was 62; whereas the minimum standard score of this Constitutional law program was be 75 .. The result of this the research would be able to solve the problems how to comprehend in reading narrative text. Research Procedure : the researcher gave Pre- Assessments that purpose got the first data about teaching and learning process in classroom by zoom. The researcher gave test for the students of reading narrative text and asked students to read it and reseacrcher gave score to know students reading achievement before implementing narrative text through Carousel Brainstorming Strategy. After that, the researcher anlyzed the result or the score of students reading. Preliminary Process, This preliminary research was done to get the more authentic data especially about English teaching and learning process. On December $3^{\text {th }} 2020$, the researcher conducted the first preliminary research at Constitutional law program of IAIN Bengkulu by interviewing the English lecturer. It was applied for obtaining the supporting first hand data about some infomation that had been done in preliminary study, such as the result of reading test in pre action and the students reading problems. Based on the cases, formed interview was used in which a list of questions is used as a guide while interviewing. The research found most of ten students especially forConstitutional law program class had low ability in reading comprehension of narrative text. The average score of students ability in reading is only 64 ; whereas the minimum standard score of the university is 75 . It could be seen from the data which was obtained from the result of the pre action test to know the students ability in reading narrative text. The English lecture explained that the students had dificulties in starting to reading, generating ideas, identify main idea in paragraph, low vocabulary so that make they do not well read. Almost all of the students did know how to start. They could not read smoothly because they did not know what to read to develop the topic and they got stuck in the middle of reading.In adition, based on the classroom observation by zoom that was done during the teaching and learning process, English lecturerr's way in teaching reading skill by zoom to students was monotonous and uninteresting. She/He only focused on the using of text book material without to involve the students to teaching and learning process. The lecturer just asked the students by zoom to remember their past experience and read them. She/ He also explained the materials of narrative text incompletely. On the other hand, the students looked bored with lecturer's explanationsby zoom.It is considerd that the teachers played an important role in teaching and learning process, especially in applying the appropriate strategy in teaching reading. The preparation covered: (1) choosing the theme/sub-theme based on subjectEnglish for law to ten students of Constitutional law program, (2) preparing the material, (3) preparing the observation guide, (4) designing the reading test by using carousel brainstorming strategy, (5) designing the creteria of success of the research.Choosing the Theme. The research consultes with the English Lecturer to choose the suitable theme of this research is "Lgal Education in Indonesia because it deals with reading 
comprehension of narrative text for Constitutional law programwhile the example of carousel brainstorming was taken from the internet.Preparing the Observation Guide, the observation guide was used to observe the real condition of teaching and learning reading process in the classroom by zoom . It was use to record the students involvement in the teching and learning process whether they are active or passive, especially reading comprehension of narrative text by using carousel brainstorming strategy. The forms of the observation guide were observation checklist that contained the indicators to be observed and field notes.

Design of criteriam In this classroom action research by zoom, the criteria of succsess was based on score in reading test. The students were considered to be succsessful if $75 \%$ of the students had achived the standard average score that was 77 or more. Beside, the students' involvement in teaching learning process was considerd succsessful if there are $75 \%$ of the students involved actively in the process of reading activities. These criteria were used as the main consideration to determine wheter the implemention of the research was succsessful or not.

In the first and second meeting, the researcher carried out the action by teaching reading using carousel brainstorming strategy to improve the ability ability of the students in reading narrative text. In this case, the researcher assigned with some exercises to write a narrative text based on their brainstorming . Meanwhile, in the third meeting, the research and English Lecturer gave the reading test to the students to measure their reading ability in reading narrative text. Clasroom Observation and Evaluation,aimed to observe the students activities during the teaching and learning proccsess of reading by using carousel brainstorming strategy by zoom. The researcher used observation checklist as the instruments in the observing students active participation. The teacher activity had been observed in form of field note. In this classroommobservation was conducted twice by via zoom. The students made their carousel brainstorming by doing some steps: (1) reading the topic in the middle, (2) thingking of as many to put the words or phrases as they can which are related to the topic, (3) trying to put the words phrases into the bubbles, (4) eliminating the imppropriate words, (5) developing their brainstorming

Coleecting Data, kinds of data in this research, namely qualitative and quantitative data. The qualitative data were gained by observation about the way the lecturer action. The quantitative and data were gained by reading test and the result of classroom observation by via zoom.Qualitative Data, in this research are attained by observbation in implementating of the action. The researcher observed the implementation of the actions in the aspect of opening the lesson, main activites, and closing the lesson by zoom. The instruments used in the observation was in a form of a field note. The observer took a note related to questions on what the doer had done in implementing the action. Quantitative Data, based on Observation by zoom was conducted twice in each activities. This observation was inteded to know the students participation when they were taught reading by using Carousel brainstorming strategy. The observation checklist wasused as instruments to record students active participation during the teaching and learning process. The indicators of the active students could be seen in asking question and aswering questions, paying attention during the lesson, using Carousel brainstorming in their prereading, proofread their partner's draft, and reading narrative text. If the students fulfilled at the least three indicators they were categorized as active students. This research was succsessfull if about $75 \%$ of the students were active in teaching and learning process of reading by using Carousel brainstorming strateg .

Research instruments werte used in this research by data collecting. The primary data and the supporting data. The instruments used the collecting primary data were observation checklist, field note, and reading test, while supporting data were gathered through an interview based on observation, Arikunto (2000)suggested that the best way for doing observation is by using observation checklist, The observation checklist was used to record the students' involments the teaching and learning process wheter they were active or passive.

In this research, English Lecture did direct observation in the classroomby zoom to know the students' participation when they were taught reading narrative text by the researcher using Carousel brainstorming strategy. On the other hand, observation was done by researcher $r$ to observe and note all of things happened in the classroom during the teaching and learning process. The indicator of active students could be seen asking questions and answering question, paying attention during lesson, using Carousel brainstorming in their prereading, proofread their partner's draft, and reading narrative text. The field note contained some questions that guide the observerin collecting data. The observer takes a note related to the questions on what the was have done in implementing the action.Test was used to know measurement the students reading comprehension to the material given that to measure the students reading comprehension. The test the students reading comprehension in pre-assessment . the research used written test to know students ability in reading and tlecture gave to students text narrative to students and then students indentify main idea sentence in the text narrative. Pre-assessment in the form multiple choice items which is consisted of 40 question. The expected answer were A, B,C And D. Each the correct answer had 1 point and incorrect answers got 0 point. The purpose of the pre-assessment 
conducted wasfind initial condition of the subject in reading comprehension. Meanwhile the preassesments would reflect the improve of Carousel Brainstorming strategy

Table 1. Criteria of scoring reading comprehension

\begin{tabular}{|c|c|c|}
\hline Variable & Sub-Variable & Indicator \\
\hline \multirow[t]{5}{*}{ Reading comprehension } & Main idea & $\begin{array}{l}\text { The students can identify the main idea } \\
\text { of the reading passage well. }\end{array}$ \\
\hline & $\begin{array}{l}\text { Understanding text } \\
\text { organization }\end{array}$ & $\begin{array}{l}\text { The students can understand well about } \\
\text { the organization or the order of the text. }\end{array}$ \\
\hline & Inferences & $\begin{array}{l}\text { The students can understand where the } \\
\text { text is refers to. So, they can understand } \\
\text { even they vocabulary of the text were } \\
\text { changed in its pronouns, etc. }\end{array}$ \\
\hline & Predicating & $\begin{array}{l}\text { The students can encourage them selves } \\
\text { to look at the subject or title of the } \\
\text { passage,and to think about the possible } \\
\text { content. If doesn't matter if the learner } \\
\text { do not predict correctly. The activity still } \\
\text { helps prepare them for reading. }\end{array}$ \\
\hline & Vocabulary & $\begin{array}{l}\text { The students can try and gues the general } \\
\text { sense difficult word, and there are a } \\
\text { number of activities which help the } \\
\text { reader deal with unfamiliar vocabulary } \\
\text { without using dictionary or asking the } \\
\text { teacher to explain and translate. }\end{array}$ \\
\hline
\end{tabular}

Eeach correct answer given a score of 1 , and for each incorrect answer given a score of 0 . there are 40 questions, then the maximum number of scores is 40 . student scores were taken from the total score (correct answers) multiplied by the total number of questions. 40 multiplied by 2.5 so that the maximum value achieved by students is 100.Arikunto (2010), stated the interview is the fastest way for collecting the research data.It wasapplied for obtaining the supporting first and hand data about some information that had been done in preliminary research, such as the result of reading test in pre action and the students' reading problems. The interview wasconducted with the English Lecturer. In this case, structured interview was used in which a list of questions is used as guide while interviewing.Documentation is supports research in the form of several students' score while applying Strategy in reading comprehension. Data Analysis, they colleted in this research, the reading are qualitative data gained from field note and quantitative data are collected from the reading achievment test score and the result of observation during the teaching and learning process. The quantitative data are analyzed the following form. The categories table can be seen as follow:

Table : Percentage of students' Score category ${ }^{2}$

\begin{tabular}{|c|c|}
\hline Score Interval & Category \\
\hline $80-100$ & Very Good \\
\hline $70-79$ & Good \\
\hline $60-69$ & Moderate \\
\hline $50-59$ & Low \\
\hline$<49$ & Failure \\
\hline
\end{tabular}

The formula bellow is used to find the students' mastery in average.

$$
\begin{aligned}
& \boldsymbol{P}=\frac{\boldsymbol{F}}{\boldsymbol{N}} \mathbf{x} \mathbf{1 0 0} \% \\
& \text { Note : } \\
& \mathrm{P} \quad \text { : The percentage of the students' reading skill } \\
& \mathrm{F} \quad \text { : Total score of the students } \\
& \mathrm{N} \quad \text { : Total number of the students }
\end{aligned}
$$




\section{RESULT AND DISCUSSIONS}

This result of the research based on the data collection and analysis. This research showed that the students' ability in comprehending narrative texts of reading comprehension.It was improved significantly. It can be proved from the comparison between the result of pre-assessment score and the students score in the last. The deatail descriptions can be explained in the following. Pre-assessment in the first step was done by the researcher. It was conducted on February $2^{\text {th }}, 2021$. It was done to get the students' basic ability in comprehending narrative texts of reading comprehension. The result of preassessment test showed that students'ability in comprehending narrative text of reading comprehension. While the teacher was teaching, there were some problems found especially in how to teach English Lecturer in this class by zoom. First, when opening the lesson, the lecturer immediately checked the attendance list of students and asked students to open their English textbooks to continue the subject matter without reviewing the lessons learned at previous meeting. Even though the activity of reviewing the lessons learned is one of important activities to help students recall the material that has been taught and its relationship with the next material.Furthermore, the lecturer explained the material too quickly so that students have not yet grasped what lecturer has taught, but $\mathrm{He} / \mathrm{she}$ has continued the material to the next discussion. Lecturer does not give students the oppotunity to ask whether they understood or not with the material being taught. He immediately asked students to do the exercises in the English textbooks and collect them when the lesson was over. In closing activity, Lecturer brought the students's assignments and corrected them at home and wasshared with the students at the next meeting. Thus, the students did not know the mistakes they have made in the assignments because it was not discussed by lecturer. The Result of Pre-AssessmentsTest, To get students' basic skill in Reading Comprehension of describing narrative text before getting action, the researcher conducted pre-assessments test by giving instruction the prepared instrument to the students on February 02, 2021. The detail caclulation can be seen in appendix about the students score in pre-assessment test. The descrption can be explained based on the following chart:

\section{Graphic : The Result of Pre-Assessment Test}

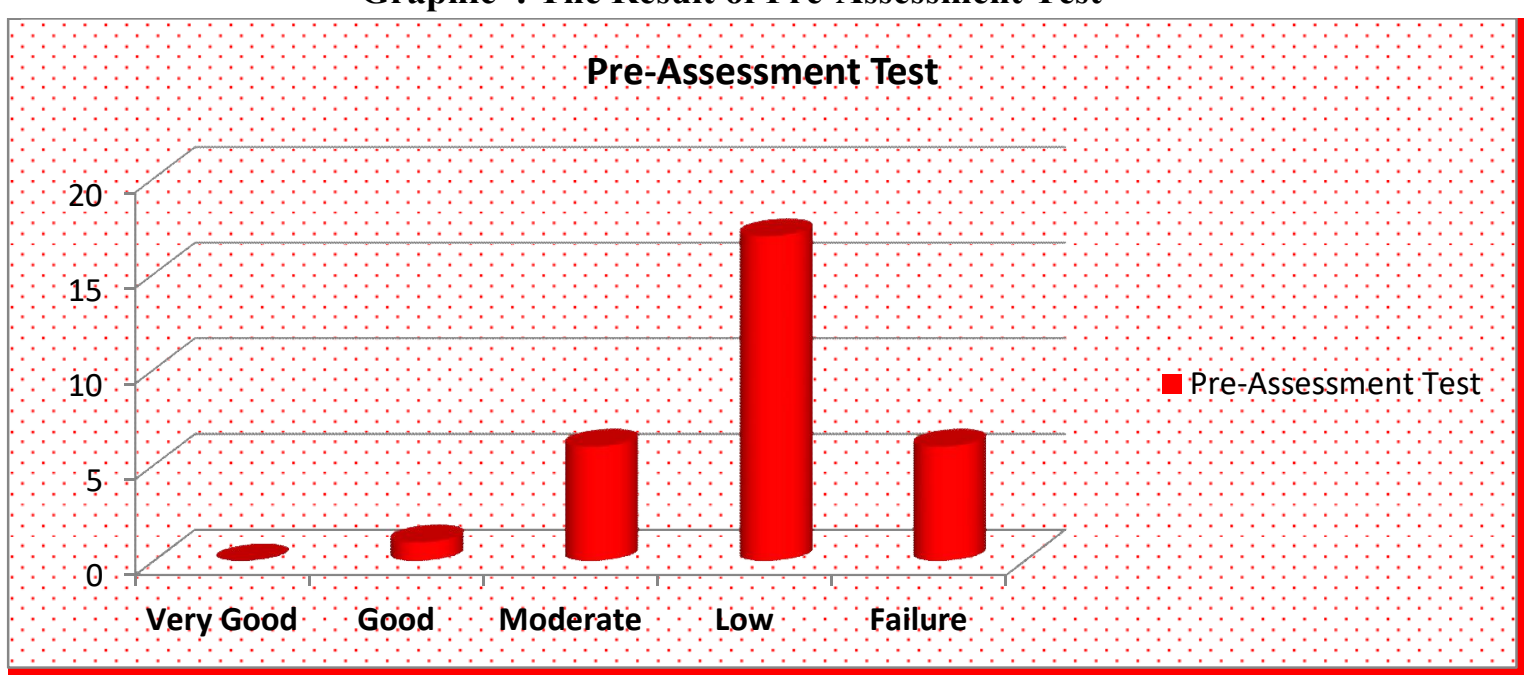

Garaphic above show that the students got 25 as the lowest score and 75 as the highest score. The students average ability in comprehending narrative texts of reading comprehension was included moderate category. For the detail explanations about students' percentage of qualification, see the following table :

Table : The Percentage of Pre Assessment Test

\begin{tabular}{|c|c|c|c|c|}
\hline No & Score Interval & Qualification & $\begin{array}{c}\text { Number of } \\
\text { the students }\end{array}$ & $\begin{array}{c}\text { Percentage } \\
(\%)\end{array}$ \\
\hline 1 & $80-100$ & Very Good & - & - \\
\hline 2 & $70-79$ & Good & 1 & $3.33 \%$ \\
\hline 3 & $60-69$ & Moderate & 6 & $20 \%$ \\
\hline 4 & $50-59$ & Low & 17 & $56.66 \%$ \\
\hline 5 & $<49$ & Failure & 6 & $20 \%$ \\
\hline
\end{tabular}

Accoding to the table above, the students' ability in comprehensing narrative texts of reading comprehension was: students (0 \%) were included into "Very Good" category; 1 student $\mathbf{( 3 3 . 3 3} \%)$ was included into "Good" category; students (20 \%) were included into "Moderate" category; 17 students $\mathbf{( 5 6 . 6 6} \%)$ were included into "Low" category; 6 students $(\mathbf{2 0} \%)$ were included into "Failure" category. The result of calculation showed that students average ability in comprehending narrative text of reading cmprehending was "Low" category with average score $\mathbf{( 5 0 , 1 )}$. The impplication principle of Crousel's 
strategy was conducted in 4 meetings. Each meeting consisted of 2 x 40 minutes by zoom. First meeting was conducted on $12^{\text {th }}$ February 2021; Second meeting was conducted on $16^{\text {th }}$ Februaryt 2021; These meetings were conducted based on strategy that had been planned. In this step, the researcher had mastered the teaching planning and activities before starting the implementation in class. By process, the implementation of the plan to see how the strategy can solve the classrooom problems. In the implementation of First meeting, researcher apllied the lesson plan that has desained before : PreLearning Activities, , Reseracher prepared the students and checked their attandance. Therefore, in this stage, the researcher did the following activities:

1) Organized the students in order to sit with group by zoom

2) Checked the students' attendance by zoom

3) Informed the students about aims of learning instruction. In this case, the objectives of Carousel Brainstorming Strategy.

4) Motivated the students in learning English, especially Reading Comprehension in describing narrative text by zoom

5) Introduction students about the Carousel Brainstorming Strategy by zoom.

While-Learning Activities can be said as score activities. These are the teaching procedure or the activites in teaching Reading comprehension Carousel Brainstorming Strategy in describing local tourism objects:

6) Researcher gave brainstorming and asking the students about the lesson.

7) Researcher asked the students to discuss of the lesson that they are going to learn of narrative.

8) Researchergave students stimuli by some questions about the lesson.

9) Researcherexplained to students that there are four tpye of questions they would encounter.

10) Researcherread a short passage aloud to the students.

11) When Researcher finished reading, read the question aloud to students and Researcher decide which type of question have been asked to answer.

12) Researcher showed to students how to find information to answer the quetion of narrative text ( $i, e$, the text, from your own experience.)

13) Researcher invited students to read another passage on their own, using a partner to determine the type of question and how to find the answer.

14) After students had practiced this process for several type of question and over several lessons, Researcher invite students to read passage and try to create different type of question for reading.

15) Researcher divided classroom into several groups by zoom. In group consist of 4-6 students

16) Researcher gave students worksheet that cotain the text of narrative and the question that should be answered by the discples.

17) The students made a small note individually about what they know and do not know from the worksheet that is give.

18) After that, the students discussed with their group to discuss the contents of the make they madeby zoom.

19) After studnets finished discussion, the teacher ask students to develop their interest experience in simple writing of reacout text on the paper.

20) Finnally, the teacher asked the students to finish it if they are not finished yet.

Post-Learning Activities, At the last part of the lesson, the activities were:

21) Researcher helped the students to make conclusion of the lesson.

22) The students expressed thier feeling about the lesson.

23) Researcher asked the students to learn more about the learning material at home and did more practice

After implementing Carousel Brainstorming Strategy in first meeting, the researcher conducted test for investigation students' progrees. The test was conducted on February 02, 2021,Carousel Brainstorming Strategy. Second meeting, Researcher taught about narrative text. Then Researcher gave stressing for the students about their weeakness in First meering especially which concerned with the rules of the strategy. In other words,this meeting was conducted to improve students' understanding about Carousel Brainstorming Strategy. The use of it instrument,and introduces material about narrative text. However, in this meeting by zoom, Reseacher focused on giving the students emphasis of improtant things by Carousel Brainstorming Strategy. In this meeting, Researcher also introduces them about short message as a new material. The text wiil be used to apply Carousel Brainstorming Strategy in order to give some

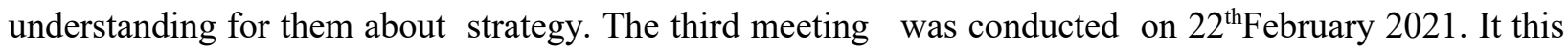
step Researcher stressed the material by viewing the students' exercicse in meeting 1 and 2 to strengthen their understanding about the Carousel Brainstorming strategy and narrative text which they have learned. 
The teacher, gave the students' evaluation test of First meeting to see their improvement in reading comprehension after action in meeting. The result of the test of First meeting in this research can be seen on the following Graphic:

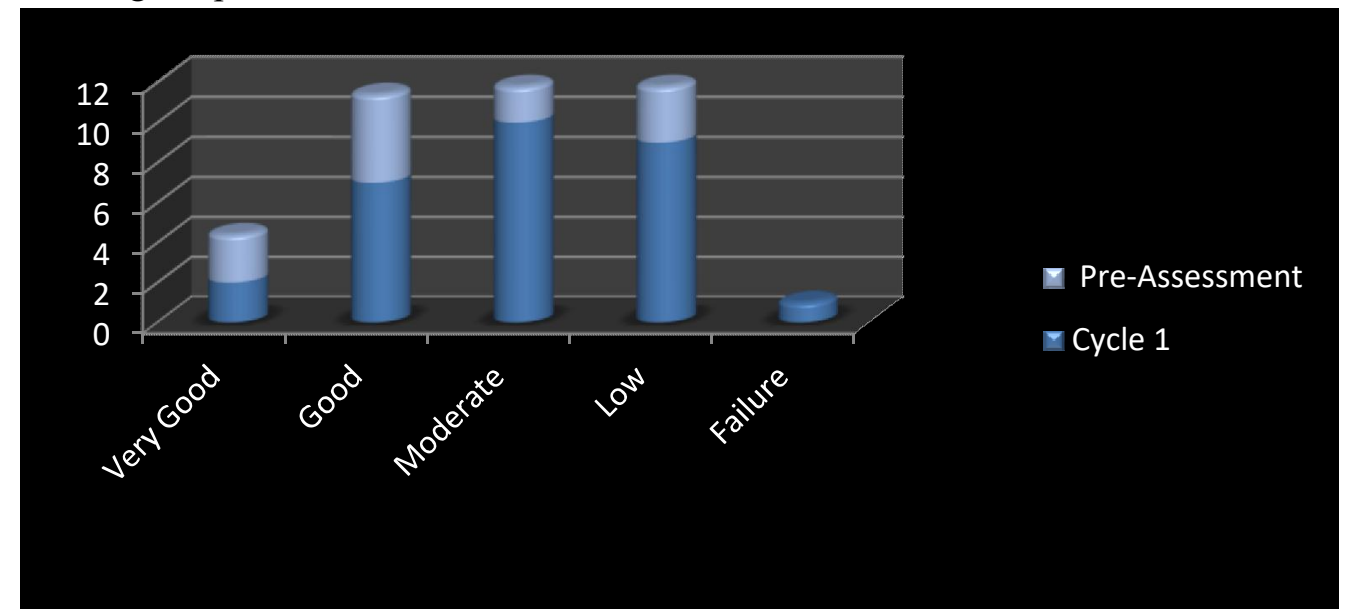

It above shows that the students got 40 as the lowest score and 86 as higher score. They average ability in comprehending narrative text of reading cpmprehension was included moderate and good category. For the detail explanations about students' percentage of qualification, see the following table

Table : The Percentage of Fist Meeting Test

\begin{tabular}{|l|c|c|c|c|}
\hline No & Score Interval & Qualification & $\begin{array}{l}\text { Number of } \\
\text { the students }\end{array}$ & $\begin{array}{c}\text { Percentage } \\
(\%)\end{array}$ \\
\hline 1 & $80-100$ & Very Good & 2 & $6.66 \%$ \\
\hline 2 & $70-79$ & Good & 7 & $23.33 \%$ \\
\hline 3 & $60-69$ & Moderate & 10 & $33.33 \%$ \\
\hline 4 & $50-59$ & Low & 9 & $30 \%$ \\
\hline 5 & $<49$ & Failure & 1 & $3.33 \%$ \\
\hline
\end{tabular}

Based on the data in the table above, the students' ability in comprehending Narrative text of reading comprehension were : 1 students' (6.66 \%) included into "Very good" category; 7 (23.33 \%) included into "Good" category; 10 students' (33.33 \%) included into "Moderate" category; 9 students' (30 \%) included into "Low" category; and 1 students' (3.33 \%) included into "Failure". The calculation shows that the students ability in comprehending narrative text of reading comprehension after giving first action was" Moderate" category. The average score in First meeting showed a significant progress (62.43). The Students' Improvement in Reading Comprehension in Describing Carousel Brainstorming Strategy, This part only gave describing about the students' improvement quantitatively and qualitatively during the action in pre-assessment, First meeting and second meeting. the procsess of teaching and learning by Carousel Brainstorming Strategy. It can be legitimated that this strategy could improve students'ability of Syariah Faculty especially Constitutional law program of IAIN BengkuluAcademic year 2018/2019. It was a recomended that teaching strategies for English lecturer The progress of students can be seen as the following chart:Students' Improvment in Reading Comprehension in DescribingCarousel Brainstorming Strategy.

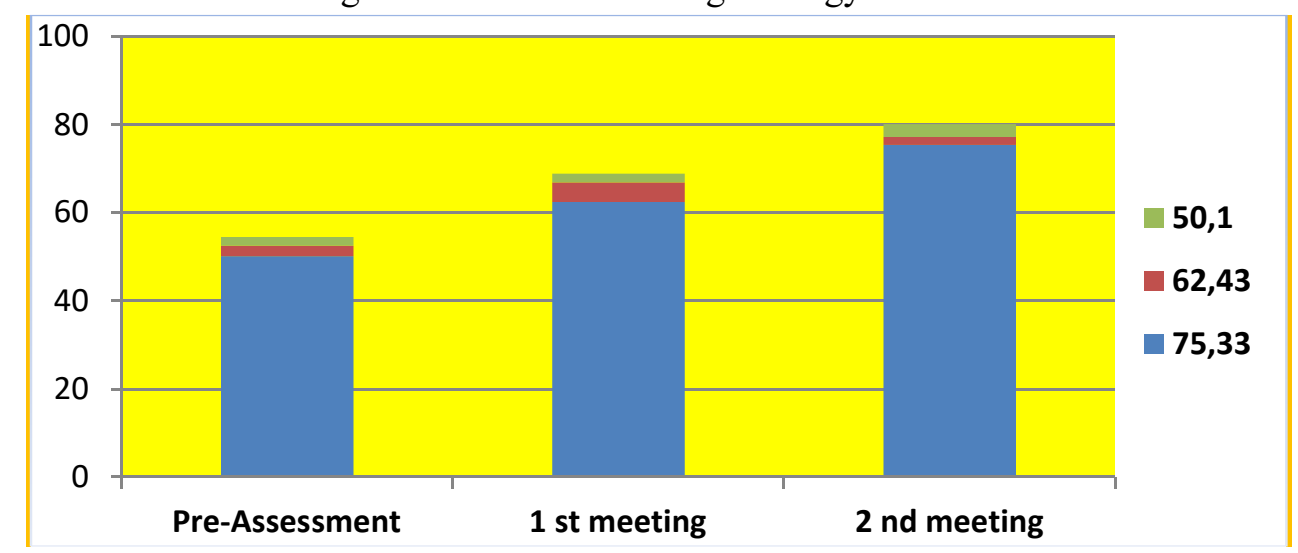

Chart above shows that the students' average score from pre-assessment until Second meeting improved significantly. In pre-assessment, the students got $(50,1)$ average score score that included into "Moderate" category. Then, in first meeting, after getting intial actions, the students average score was improved. They got $(62,43)$ that was included into "Moderate" category. In the second meeting, the students got significant improvement in their average score. They got $(75,33)$ that was included into "Good" category. In this stage, the researcher stopped to give the students actions because they had reached the research target. The result of test of Second meeting in this research can be seen on the following Chart: 
The Result of the Second meeting test

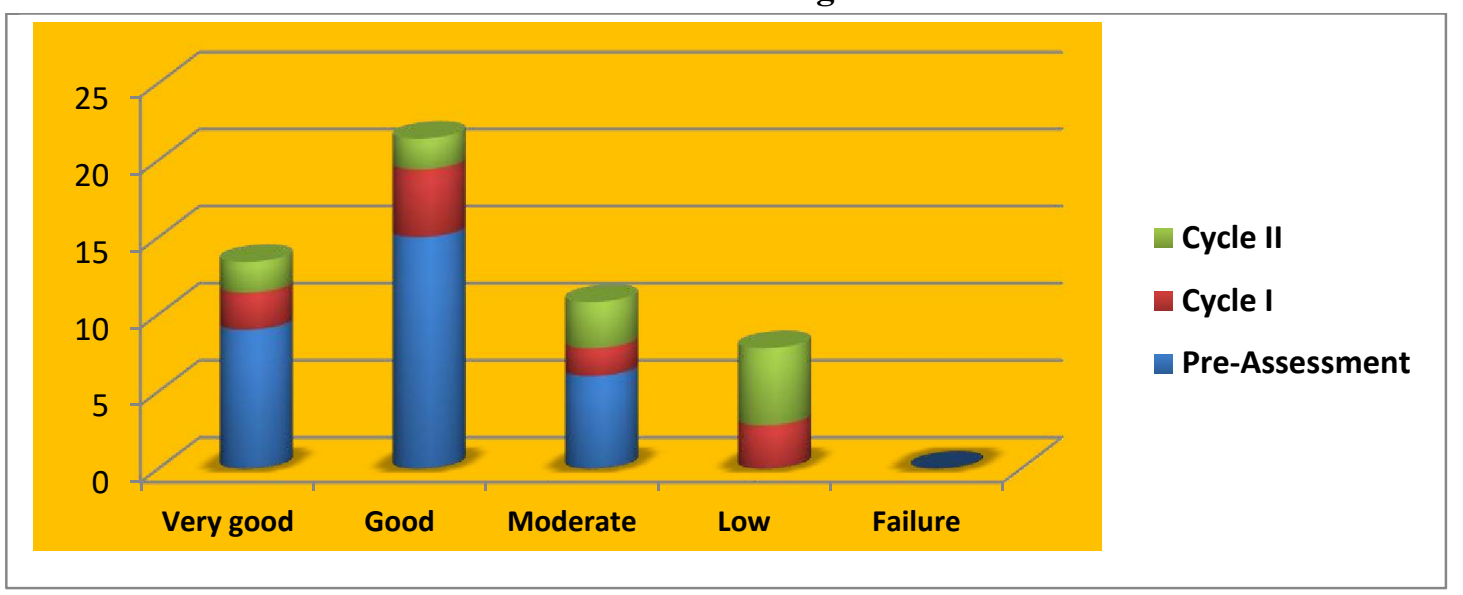

Chart above shows that the students got 60 as the moderate score and 90 the highest score. The students' average abilty in comprehending narrative texts of reading comprehension was included very good category. For the detail explanation about students' percentage of qualification, see the following table.

Table : Percentage of second meeting Test

\begin{tabular}{|l|c|c|c|c|}
\hline No & Score Interval & Qualification & $\begin{array}{l}\text { Number of the } \\
\text { students }\end{array}$ & $\begin{array}{l}\text { Percentage } \\
(\%)\end{array}$ \\
\hline 1 & $\mathbf{8 0 - 1 0 0}$ & Very Good & 9 & $30 \%$ \\
\hline 2 & $70-79$ & Good & 15 & $50 \%$ \\
\hline 3 & $60-69$ & Moderate & 6 & $20 \%$ \\
\hline 4 & $50-59$ & Low & - & - \\
\hline 5 & $<49$ & Failure & - & - \\
\hline
\end{tabular}

Based on the data in the table above, the students' ability in comprehending Narrative texts of reading comprehension were: 9 students' (30 \%) included into "Very Good" category; 15 students' (50,1\%) included into "Good" category; 6 students' $(\mathbf{2 0} \%)$ included into "Moderate" category and there was no students' who included into "Low and "Failure". The calculation shows that students' ability in comprehending Narrative text of reading comprehension after giving first action was "Good" category. The average score in cycle I showed a significant progres (75.33).

Based on the data, which were collected in the process of four meeting, the research found thatthe students had been succeeded in comprehending narrative text of reading comprehension. Most of the students' had understod about the process and implementation of Carousel Barainstorming Strategy. They looked very enthusiam and high motivation in improving their reading comprehension skill. Finally, from the students distribution score in second meeting, it was obvious that there was very significant improvments made by students' in comprehending Narrative texts of reading comprehesion. Between the students' average score in second meeting and Pre-Assessment test. It mean that Carousel brainstorming Strategy is one of the strategies to apply by teachers to improve students' ability in comprehending narrative texts of reading comprehension, This research showed that the students' ability in comprehending narrative texts of reading comprehension was improved significantly after the researcher gave the students actions byCarousel brainstorming Strategy which consisted of four meeting. this research indicated that it is one of appropriate teaching strategy to improve stuedents ability in comprehending narrative texts of reading comprehension and gave the motivation for them such as expressed by experts.According to Ruorbel, carousel brainstorming provides and opportunity to generate lot of idea in resonss to different prompts as well as to thingking of others in group. Point out that Carousel brainstorming allow a lecturer to have students pull out and thingking about what they know about subtopic within a large topic in reading.

This strategy is also activating and motivation background knowledge and to check understanding after studying a general topic.Carousel brainstorming strategy is aproprite strategy in teaching reading comprehension it requires students to acsess background knowledge or review what they have learned by thingking about subtopic within a boarder topic. This strategy also uncrease students reading skill.This strategy provides an opportunity to make sure that everyone is aware all the ideas that are generated because it realise on group this strategy also applies to improve reading skill.Firstly, the researcher conducted pre-assessments test to know the students' basic skill in comprehending narrative texts of reading comprehension. The result shows that the students' avarage ability in comprehending narrative texts of reading comprehension was included into "poor" category with average $\mathbf{( 5 0 , 1 )}$. The students got (26) as lowest score and (75) as the highest score. The caluculation showed that the students' average ability in comprehending narative text of reading comprehension was : 0 students (0\%) were included into "Very good" category; 1 student $\mathbf{( 3 . 3 3}$ \%) were included into "Good" category; 6 students (20 \%) 
were included into "Moderate" category; 17 students (56.66 \%) were included into "Low" category; 6 students (20 \%) were included into "Failure" category "Low" category with average score $\mathbf{( 5 0 , 1 )}$. Secondly, the results of first meeting show that the students' ability in comprehending narrative texts of reading comprehension was included into "Moderate" category with average score (62.43). it show significant improvement after the fisrt meeting given. The students lowest score was (40), and higher score was (86). There were 2 students' (6.66 \%) included into "Very good" category; 7 students' (23.33 \%). Included into "Good" category; 10 students' (33.33 \%) included into "Moderate" category; 9 students' (30 \%) included into "Low" category; 1 student $(\mathbf{3 . 3 3} \%)$ included into "Failure". Thre calculation shows that the students ability in comprehending Narrative text of reading comprehension after giving first action was "Moderate" catergory.

The average first meeting showed a significant progres (62.33). In this step, the researcher found that almost all of the students'basically have good basic skill of reading comprehension at that time. It needed time to make them familiar with the strategy. The result of the first meeting showed significant improvement of the students ability in comprehending narrative texts of reading comprehension, but the target of the research has not achieved yet.Thirdly, Second meeting showed that four was a significant improvements made by the students' in comprehending narrative texts of reading comprehension. The students' average score was (75.33). There were: 9 students' (30 \%) included into "Very good" category; 15 students' (50\%) included into "Good" category; 6 students' (20 \%) included into "Moderate" category. Who imcluded into "Low and there was no included Failure". The calculation show that the students ability in compreheding Narrative text of reading comprehension after giving first action was "Very good" category. The average score in second meeting showed a significant progresss (75.33). Finally, after giving the actions from first meeting andsecond meeting, lecturer succeeded improving the students' ability in comprehending narrative texts of reading comprehension. It can be proved by the comparison result between students' ability comprehending narative text of reading comprehension in pre-assessment test and second meeting showed significant improvement. In preassessment, the students' average was included "poor" category with average score (50,1). Second meeting, the students' average score was included "Good" category with average score (75.33).based on discussion above, it is obvious that Carousel Brainstorming Strategy is an effective strategy to apply bylecturer in order to help students in improving their ability in comprehending narrative texts of reading comprehension and gave high confident for develop their motivation Constitutional law program of IAIN Bengkulu. In addition, the process of Carousel Brainstorming Strategy was regarded as innovative activity in teaching reading texts for students'.

\section{IV.CONCLUSIONS}

Based on calculating process of the data, the result of this research showed that Carousel Brainstorming Strategy can be improve students' ability in comprehending narrative texts of reading comprehension. The result of this research showed that the students reading comprehension of narrative text in every cycle was significant improve. The students mean score of pre-assessment was 50,1. Then in test first meeting, students got mean score 62.43, in Second meeting, students got mean score 75.33. The mean score from each meeting showed that students reading comprehension was improve. It is also suppoted by results of observational data, and documentation that shows that there is an increase in students motivation and involvement in the process of learning and teaching. It can be seen from the students score in pre-assessment test and Second meeting. In pre-assessment test the students'average was included "Poor" category with average score $\mathbf{( 5 0 , 1 ) . ~ I n ~ t h e ~ s e c o n d ~ m e e t i n g , ~ t h e ~ s t u d e n t s ' ~ a v e r a g e ~ s c o r e ~}$ was included "Good" category with average score (75.33). It mean that Carousel Brainstorming Strategy gave many contributions for students' ability in comprehending narrative texts of reading comprehension and giving motivation how to comprehend the reading text at Constitutional law program of IAIN Bengkulu.

\section{ACKNOWLEDGMENTS}

The Author is grateful to English Departement Students Of IAIN Bengkulu and Syariah Faculty forsupporting this research. I also thanked to Dean of TADRIS (Tarbiyah Bahasa English) and Dean of Syariah Faculty for invaluable advices.

\section{REFERENCES}

\{1] H.Douglas Brown. 2004.Teaching by principles An Interactive Approach to la nguage pedagogy.Third Edition: San Francisco.

\{2\} Rika Fidda Yuli. 2013. Jounal of English Language Teaching: Using Brainstorming. 
\{3\} Rania Adel Ibrahim Ahmed. 2015 (Enhancing Elementary Level EFL Students' Reading Comprehension and Writing Skills through Extensive Reading Enrichment Program):International Journal of English Education.

[4] Rosma Hartini Sam's.2010.Metode Penelitian Tindakan Kelas: Teknik Bermain Konstruktif untuk Peningkatan Hasil Belajar Matematika.Yogyakarta :Teras. P.94

[5\} Pradiyono, as quoted by Nurainun, Improving the students reading comprehension narative text by using concept oriented reading instruction at grade VIII private islamic junior high school Ali imron medan.2017, p. 23

[6] Siti Khasinah. 2013. (Classroom Action Research: Journal Pionir)

[7\} Sadimin.2017. Classroom action research management trainingmodel for senior high school teachers aided by e-module.

[8] Osama Yousif Ibrahim Abualzain. 2017. Exploring the impact of free Voluntary Reading In Upgrading Univesity students' Creative Writing At Al Baha University.( Saudi Arabia : Al Baha University.

\{9\} Emi Latifah, 2012. The implementation of carousel brainstorming in teaching reading comprehension at Man 3 Kota Cirebon.

$\{10\} \quad$ Feng Liu. 2010Internasional Education Studies : Reading Abilities and Strategies: A Short Introduction.

\{11] M. Bojovic1. (2010). Reading Skills and Reading Comprehension in English for Specific Purposes.( Agronomy Cacak, Serbia: University of Kragujevac)

\{12\} Qismullah Yusuf, 2017.(Skimming and Scanning Techniques to Assist EFL Students in Understanding English Reading Texts).Wildhan Burhanuddin. 2015. (Journal Keguruan dan ilmu pendidikan).

\{13\} Purnama Syae Purohman.2018 (Classroom Action Research Alternative Research Activity for Teachers)

$\{14\} \quad$ Yusuf \& Fauzan In Qismullah Yusuf, 2017. (Skimming and Scanning Techniques to Assist EFL Students in Understanding English Reading Texts)

\{15\} Suharsimi Arikunto. Prosedur Penelitian Suatu Pendekatan Praktik : Jakarta : PT. Rineka Cipta,2014, P. 199Adapted from Lewin, in Elliot, $1991 . \quad$ P. 70

\{16\} Harmer,Jeremy. 2005. The practice of English Language Teaching. London: Longman.

\{17\} Wiliam Grabe and Fredricka L. Stoller.2013Teaching and Researching Reading ( Routledge Published, London and New York)

\{18] Beatrice S. Mikulecky and Linda Jeffries. 1996. More Reading Power. of the world language Division: Longman.

\{20\} Mandler and Deforest, Stein, Nezworski in Janette K. Klingner.2007. Teaching Reading Comprehension to Students with Learning Diffculties. New York: London.

\{21] Erbu kaya, 2015 ( The of Reading skills on Reading Comprehension Ability of Turkish EFL Students). Universitepak Bulten.

\{22] I.S.P. Nation.2009.Teaching ESL/EFL Reading and Writing. New York: London. 